Leontiy Voitovych (Леонтій Войтович)

Lwowski Uniwersytet Narodowy im. Iwana Franka

ORCID ID: 0000-0002-9191-6537
OBLICZA WOJNY

TOM 5 - MIASTO I WOJNA

ŁóDŹ2021 • ISBN 978-83-8220-699-9 • s. 225-242

https://doi.org/10.18778/8220-699-9.13

\title{
CZOŁGOWY BÓJ NA RYNKU W MIKOŁAJOWIE NAD DNIESTREM 1 LIPCA 1941 ROKU
}

Streszczenie. W artykule na przykładzie jednego ze starć czołgów na rynku w Mikołajowie nad Dniestrem pokazano niektóre z przyczyn klęski wojsk radzieckich na początku wojny radziecko-niemieckiej. Okoliczności tego starcia są po części znane dzięki zachowanym niemieckim zdjęciom. W tekście podjęto próbę wyjaśnienia, jak niemiecka 101. Dywizja Piechoty Lekkiej, w której składzie nie było żadnego czołgu, mogła pokonać jednostki radzieckie wyposażone w najpotężniejsze wówczas czołgi KW-1 i KW-2. Przeanalizowano również przyczyny błędów dowództwa radzieckiego, które nie było w stanie określić kierunków głównych uderzeń wroga i nie potrafiło zorganizować skutecznej obrony, mając zdecydowaną przewagę zarówno w ludziach, jak i w sprzęcie wojskowym. W tym kontekście widać dobrze bohaterstwo zwykłych żołnierzy radzieckich, którzy walczyli do końca. Szczególną uwagę zwrócono na specyfikę walki czołgów w warunkach miejskich, kiedy to Niemcom udało się wyeliminować z walki czołgi ciężkie KW-1, które trudno było zniszczyć nawet słynną armatą przeciwlotniczą kalibru $88 \mathrm{~mm}$ - w tym wypadku niemieccy żołnierze skutecznie je niszczyli za pomocą lekkiej armaty przeciwpancernej kalibru $28 \mathrm{~mm}$.

Słowa kluczowe: początek radziecko-niemieckiej wojny, Mikołajów, zbrodnie NKWD, bój czołgowy, walka w terenie zurbanizowanym

Druga wojna światowa pozostawiła wiele pytań bez odpowiedzi, wiele tajemnic i wiele okazji do ich wyjaśnienia. W dramatycznych wydarzeniach - obok chaosu i nieudolności dowództwa wyższego szczebla - niemal zawsze ujawniały się także odwaga, wierność przysiędze i poczucie żołnierskiego obowiązku, które do dziś budzą podziw. Jednym z takich epizodów drugiej wojny światowej były wydarzenia z 1 lipca 1941 r. na rynku w Mikołajowie nad Dniestrem. Nie zostały one odnotowane w raportach frontowych, lecz zasługują, by 
o nich wiedziano i pamiętano. Co więcej, wydarzenia te odzwierciedlają przebieg i przyczyny klęski radzieckich wojsk pancernych w czerwcu-lipcu 1941 r., w której sami czołgiści - wypełniający do końca swój obowiązek - wykazywali się wielkim bohaterstwem. „Czołgowy” epizod mikołajowski z 1 lipca $1941 \mathrm{r}$. jest udokumentowany w Kronice Włodzimierza Fedusewicza, zachowały się także zdjęcia wykonane przez fotografów ze szwadronu rowerzystów batalionu zwiadowczego niemieckiej 101. Dywizji Piechoty Lekkiej .

Według tekstu W. Fedusewicza:

na środku Rynku na kamiennym cokole stał dawny monumentalny żelazny krzyż, na którym był dawny napis napisany pismem cerkiewno-słowiańskim. Stał on do 1941 roku, do 1 lipca tego roku, kiedy Niemcy nacierali na Mikołajów, a bolszewicy wycofywali się. Jeden z wielkich czołgów bolszewickich jechał przez Rynek prosto na tą figurę i po chwili z pięknego, ogrodzonego parkanem, pomnika odwiecznego pozostała kupa gruzu. Krzyż żelazny został zmiażdżony, a obelisk, na którym stał krzyż, powalony i do połowy zniszczony. Pomnik przestał istnieć, ale za około trzy godziny po tym, granat niemiecki trafił w ten czołg $\mathrm{i}$ on rozłamany na dwoje, leży nadal w południowej stronie Rynku, naprzeciw domu b. Winicza-Szora, Żyda, w którym mieścił się urząa bolszewicki do zapisu aktów stanu cywilnego. (...) Ten dom zapalił się od ognia armatniego, kiedy się o tym dowiedziałem, mimowolnie wskoczyłem do tego domu. Kazałem dookoła siebie lać wodę, poparzyłem sobie ręce, lecz uratowałem księgi metrykalne ze wszystkich cerkwi, kościołów, synagog rejonu mikołajowskiego. Nasza parafia nie straciła żadnej księgi. Z pomocą p. Iwana Kryśka i jeszcze dwóch mieszczan przewiozłem te księgi wózkiem ręcznym do cerkwi św. Mikołaja, a stąd każdy ojciec proboszcz zabrał sobie swoje księgi (...) księgi metrykalne, jak wspomniałem wyżej, zostały uratowane przez mnie 1 lipca 1941 r., kiedy do Mikołajowa o godzinie 3 weszły wojska niemieckie².

W rosyjskojęzycznej wersji Historii miast i wsi URSR. Obwód lwowski podano, że cztery czołgi z 23. i 24. Pułku Pancernego radzieckiej 12. Dywizji

${ }^{1}$ Zdjęcia te zostały opublikowane w różnych opracowaniach niemieckich, włoskich i rosyjskich, w tym słynnego rosyjskiego historyka wojskowości Aleksieja Isajewa w pracy Frontowe ilustracje. 1941. Walki na Ukrainie (А. ИСАЕв, Бои на Украине1941, „Фронтовая имлюстрация” 2004, № 4), ale nigdy w podpisach pod tymi zdjęciami nie zaznaczono, że zostały one wykonane w Mikołajowie. Dzięki konsekwentnej postawie entuzjastów badających miejsca dawnych bitew, w tym Jurija Morguna (Odessa), Konstantina Kowałyszyna (Lwów), Jegora Okuniewa (Petersburg), Andrieja Karpowa, Siergieja Łotariewa i Denisa Kołokolczykowa (Moskwa), zdjęcia te zostały prawidłowo zidentyfikowane i wprowadzone do obiegu naukowego.

2 В. ФЕдуСевич, Хроніка парохії і міста Миколаїва над Аністром, [в:] Миколаӥвщина. Збірник наукових статей, т. 1: Відпов, реА. А. Войтович, Аьвів 1998, с. 183-184. 
Pancernej przez dwa dni bohatersko powstrzymywały atak niemiecki na Mikołajów. Załogi czołgów zginęły, a ich personalia do dziśs nie są znane ${ }^{3}$. Autorzy artykułu wspominają o starciu czołgów (podając przy tym, że przed wojną owa dywizja stacjonowała w Stryju), lecz informacje te budzą poważne wątpliwoścí ${ }^{4}$.

Mikołajowski krajoznawca Iwan Tabaczar słyszał od świadków tego starcia ciekawą wersję omawianych wydarzeń. Według niej Niemcy przyjechali do Mikołajowa na rowerach. Ta informacja jest wiarygodna. Dnia 1 lipca 1941 r. o godzinie 15.00 pododdziały 101. Dywizji Piechoty Lekkiej wkroczyły do miasta. Oczywiście jako pierwsi znaleźli się na miejscu żołnierze batalionu zwiadowczego. Zgodnie z etatem batalion zwiadowczy dywizji tego typu miał dwa szwadrony rowerowe i kompanię przeciwpancerną wyposażoną w armaty kalibru $37 \mathrm{~mm}$. Według informacji zebranych przez I. Tabaczara, gdy radziecki czołg jeździł po rynku, rowerzyści obeszli go bocznymi uliczkami i zajęli stanowiska w domu Winicza-Szora (w którym wówczas znajdował się Urząd Stanu Cywilnego), skąd rzucili granat, który rozerwał gąsienicę. Czołg wystrzelił z armaty w kierunku budynku i go podpalił. Na zdjęciu, na którym płonie czołg KW-2, widać z prawej strony dom z wyraźnymi śladami po trafieniu pociskiem armatnim, z wybitymi oknami i drzwiami (ryc. 1).

Do tego momentu informacje $\mathrm{z}$ wszystkich źródeł są zbieżne. Informatorzy I. Tabaczara także opowiedzieli o dwóch zabitych Niemcach, którzy zostali pochowani na placu, jak również o dwóch poległych radzieckich czołgistach, z których jeden zastrzelił się po długim przebywaniu w czołgu. Obaj czołgiści zgodnie z relacją W. Fedusewicza zostali pochowani na cmentarzu. Kolejne zdjęcia pokazują już czołg zniszczony przez eksplozję, którego części zostały rozrzucone w różnych kierunkach. Te fragmenty czołgu przetrwały do końca wojny i widziało je wielu mieszkańców miasta Mikołajowa (ryc. 2). Na zdjęciach można zobaczyć także porzucony motocykl i samochód sztabowy (ryc. 3).

3 А. МАРКевИЧ, М. ОРел, В. СТАСИв, Николаев, [в:] История городов и сел Украинской СРСР. Аввовскал область, Киев 1978, с. 433.

4 Dywizja ta już 23 VI 1941 r. została przydzielona do 6. Armii, a następnie do 4. Armii. Od 25 czerwca brała udział w ciężkich walkach w kierunku Brodów i Dubna, gdzie została stoczona największa bitwa pancerna drugiej wojny światowej. Dnia 1 lipca większość czołgów tej dywizji już płonęła w okolicach Brodów i Dubna. Tam poległ m.in. ppłk P.I. Wołkow, dowódca 24. Pułku Pancernego. Część jednostki wycofała się do Płoskirowa (obecnie Chmielnicki). Dowódca dywizji, generał-major Timofiej Myszanin, poległ 28 czerwca, podrywając żołnierzy do ataku w pobliżu Brodów. Większość czołgów w tym czasie już stracono, więc mało prawdopodobne, aby pojawiły się w Mikołajowie. 


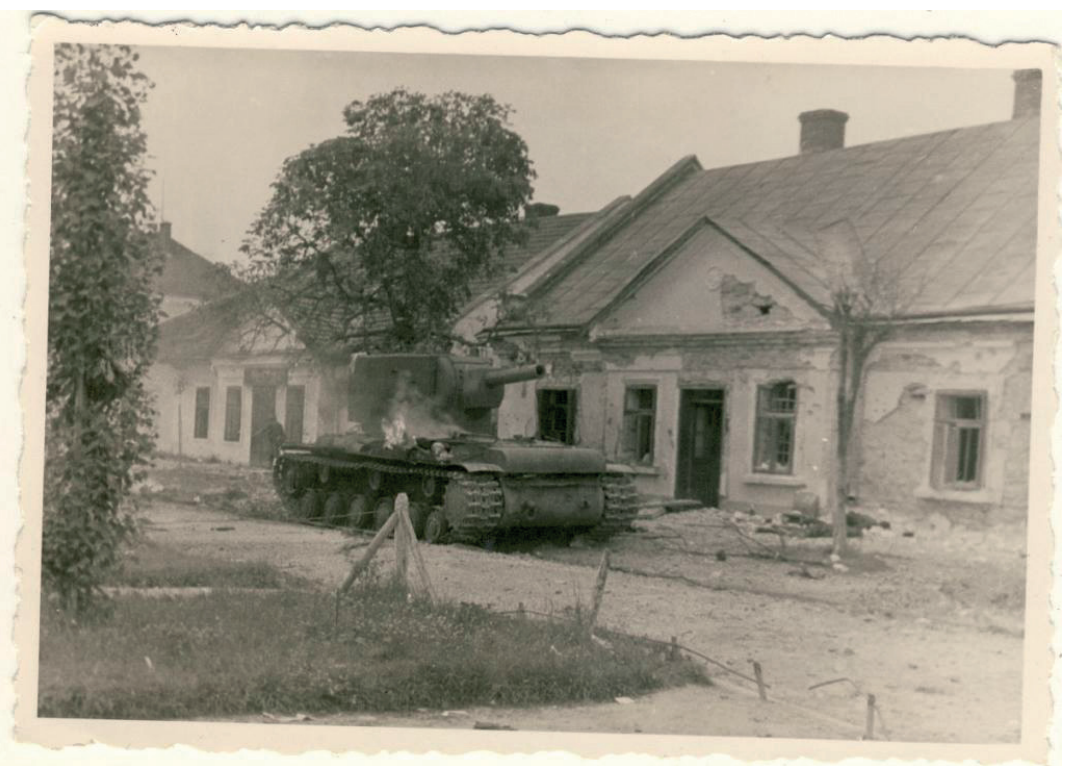

Ryc. 1. Czołg KW-2 na początku bitwy w centrum miasta. Płonie skrzynka narzędziowa z częściami zamiennymi i narzędziami przechowywanymi w oleju, podpalona zapewne pociskami $37 \mathrm{~mm}$ (źródło: Л. Войтович, Загадки „миколаївських” танків, http://mykolayiv.org/detail/zagadki-mikolayivskih-tankiv/photo/, dostęp: 15 VII 2021)

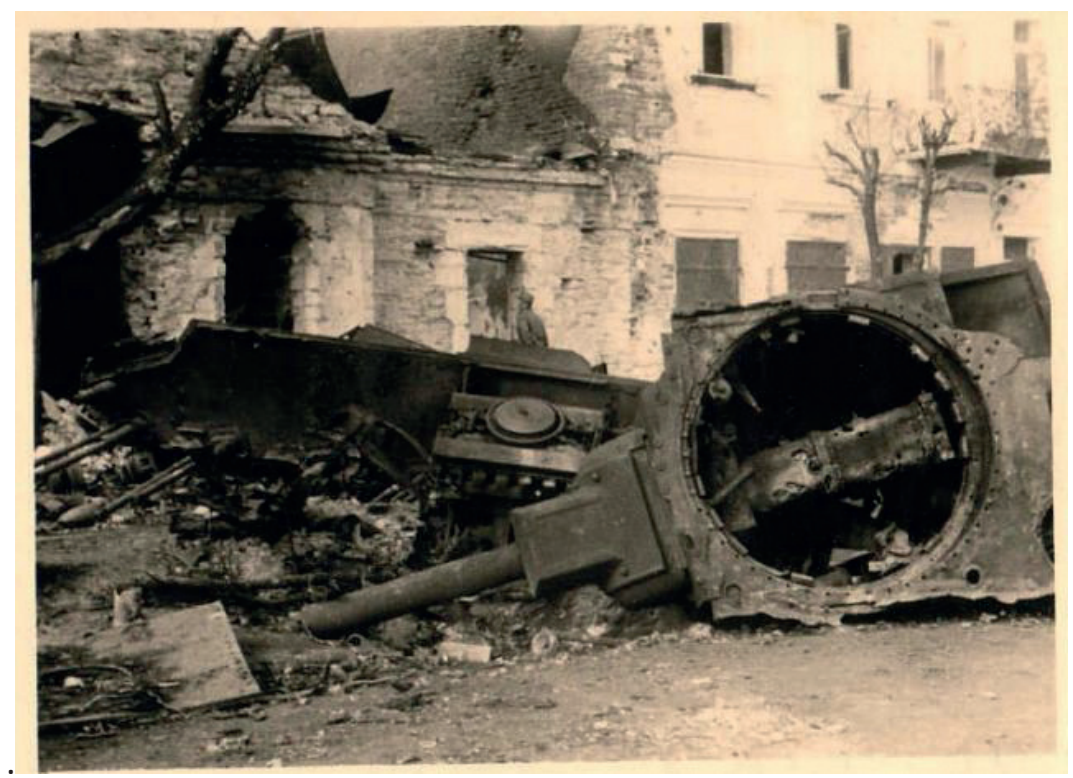

Ryc. 2. Czołg KW-2 po eksplozji (źródło: Л. Войтович, Загадки „миколаївських” танків, http:// mykolayiv.org/detail/zagadki-mikolayivskih-tankiv/photo/, dostęp: 15 VII 2021) 


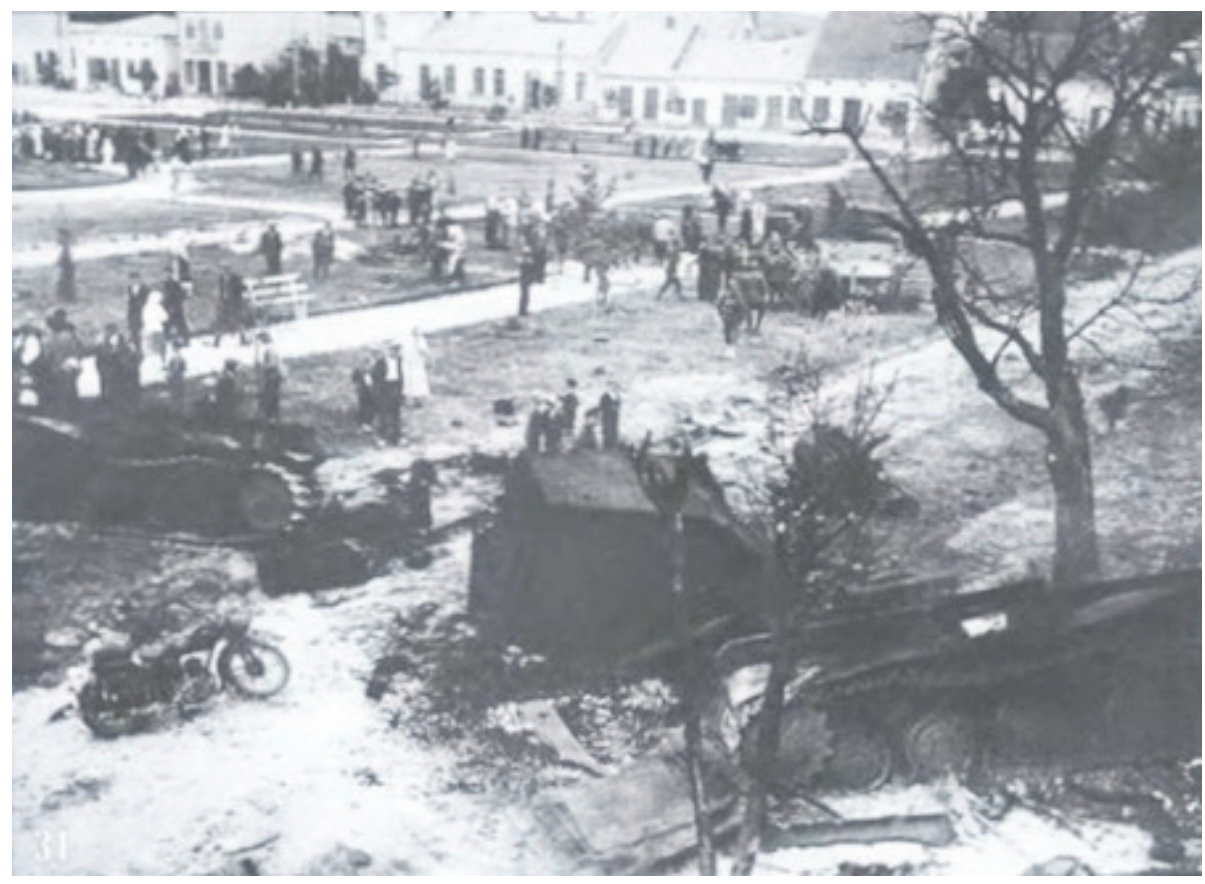

Ryc. 3. Plac Rynek po bitwie pancernej (źródło: А. Исаев, Бои на Украине 1941, „Фронтовая иллюстрация” 2004, №4, с. 41)

Inne zdjęcia przedstawiają czołg KW-1, w którego pobliżu leżą dwaj martwi czołgiści (ryc. 4 i 5). Właśnie o tych dwóch żołnierzach opowiadali świadkowie I. Tabaczorowi. Jednak żołnierze batalionu zwiadowczego niemieckiej 101. Dywizji Piechoty Lekkiej nie mogli zniszczyć czołgu z dużej odległości, bowiem nie dysponowali bronią, która by na to pozwalała 5 .

Posiadane przez niemieckich żołnierzy armaty przeciwpancerne kalibru $37 \mathrm{~mm}$ mogły pozostawić co najwyżej słabe wgniecenia w pancerzu potężnego KW-1 - ślady takie są zresztą widoczne na zdjęciach. Z kolei granatem z bliskiej odległości można było rozerwać gąsienicę, lecz to nie spowodowałoby zniszczenia czołgu (ryc. 6).

${ }^{5} \mathrm{KW}-2$ był wówczas najpotężniejszym czołgiem świata. Grubość jego przedniego pancerza wynosiła $75 \mathrm{~mm}$, a tylnego $60 \mathrm{~mm}$. Płyty pancerne były nie do przebicia nie tylko dla zwykłych dział przeciwpancernych kalibru $37 \mathrm{~mm}$, które znajdowały się na wyposażeniu dywizji, ale także dla dział przeciwlotniczych kalibru $88 \mathrm{~mm}$, których Niemcy używali przeciwko czołgom T-34. Należy zaznaczyć, że 101. Dywizja Piechoty Lekkiej nie posiadała takich dział. 

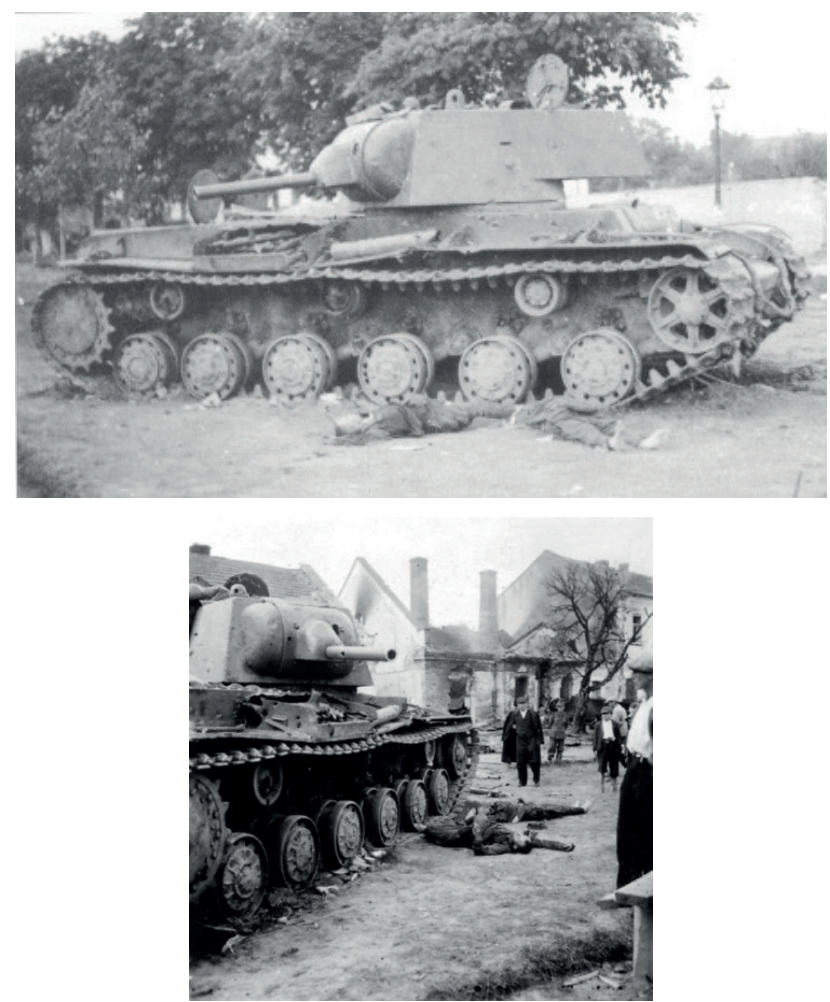

Ryc. 4 i 5. Czołg KW-1 z przestrzeloną lufą, a przy wraku pojazdu ciała dwóch poległych czołgistów (źródło: Я. Муха, Загадки миколаївських танків, http://mykolaiv.info/statti-ta-naukovi-pratsi/zagadki-mikolayivskih-tankiv.html, dostęp: 15 VII 2021)

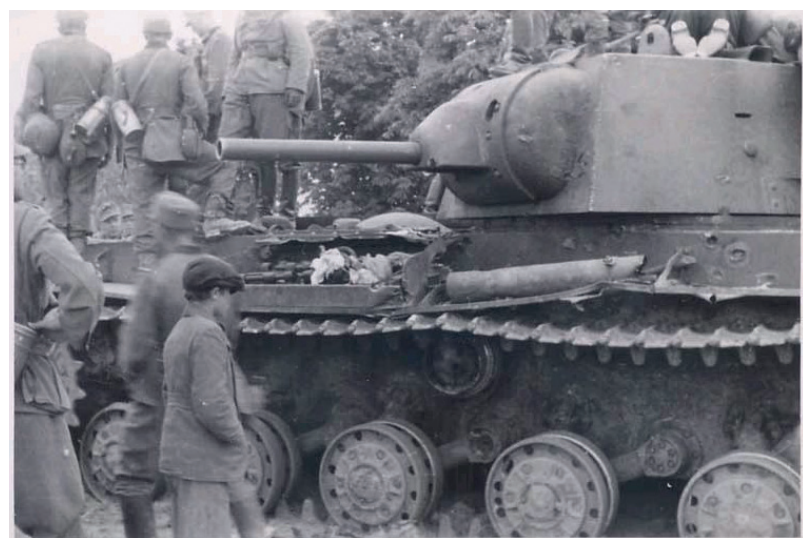

Ryc. 6. Niemieccy żołnierze na czołgu KW-1 na Rynku w Mikołajowie - zaraz po bitwie (źródło: Л. Войтович, Загадки „миколаївських” танків, http://mykolayiv.org/detail/zagadki-mikolayivskih-tankiv/photo/, dostęp: 15 VII 2021) 
Jarosław Gnatiw, który na własne oczy widział rozerwany na części czołg, w swojej książce Kiedy rycerz się obudzi (Коли прокидається лищар) podał inną wersję wydarzeń. Według niej Niemcy, osłonięci zasłoną dymną, założyli minę, której wybuch całkowicie zniszczył czołg. Ale ta wersja jest również mało prawdopodobna ${ }^{7}$, bowiem zdjęcia czołgu po eksplozji nie pozostawiają wątpliwości, że eksplodowała znajdująca się w jego wnętrzu amunicja do potężnej haubicy $152 \mathrm{~mm}$ M-10T, w którą wyposażony był czołg KW-2. Taki wybuch mógł rozerwać ciężki czołg na strzępy.

Związek Radziecki, przygotowując się do wojny, stworzył potężne sily pancerne ${ }^{8}$. Według stanu z 22 czerwca 1941 r. w Robotniczo-Chłopskiej Armii Czerwonej znajdowało się 25886 czołgów, w tym 1225 czołgów T-34 oraz $636 \mathrm{KW}-1$ i KW-2. Dawało to w sumie 1861 czołgów, których pancerza nie mogty przebić pociski wystrzeliwane $\mathrm{z}$ dział, $\mathrm{w}$ jakie wyposażona była w tym czasie większość niemieckich czołgów oraz jakimi dysponowały pododdziały dywizyjnej artylerii przeciwpancernej. Wszystkie inne kraje świata nie miały łącznie tak wielu czołgów, co Armia Czerwona. Na dzień 22 czerwca 1941 r. Wehrmacht posiadał 6852 czołgi, w tym używane wciąż lekkie czołgi Panzerkampfwagen I ${ }^{9}$ oraz zdobyczne czołgi francuskie i czeskie ${ }^{10}$. Dlaczego wojkka sowieckie, dysponując tak dużą przewagą w broni pancernej, cofały się aż do Moskwy, wciąż nie zostało jednoznacznie wyjaśnione ${ }^{11}$.

\footnotetext{
${ }^{6}$ Vide: Я. ГНАТів, Коли прокидається лицар, $\Lambda$ ьвів 2006.

7 Zwiadowcy nie byli uzbrojeni w miny przeciwpancerne. Ponadto Wehrmacht nie miał na wyposażeniu min zdolnych do pełnej neutralizacji czołgu KW (grubość dolnego opancerzenia kadłuba wynosiła $40 \mathrm{~mm}$, była więc większa od grubości przedniego pancerza ówczesnych niemieckich czołgów).

${ }^{8}$ Jednak twórca i organizator tego procesu, komandarm II rangi Iwan Chałepski (1893-1938) i jego współpracownicy zostali rozstrzelani jako szpiedzy. Większość projektantów i dyrektorów fabryk czołgów została uwięziona.

${ }^{9}$ Faktycznie była to tankietka: waga $-5,4 \mathrm{t}$, opancerzenie $14-18 \mathrm{~mm}$, uzbrojenie -2 karabiny maszynowe 7,92 mm MG 13.

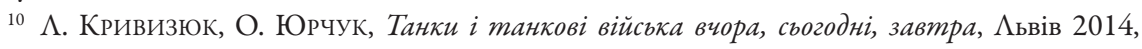
c. 202-203.

11 „Biorąc pod uwagę takie czynniki, jak ogromne trudności zaopatrzeniowe Niemców, słaby rozwój sieci drogowej w Rosji, nieoczekiwaną siłę oporu, błędne kalkulacje co do rezerw rosyjskich oraz fakt, że Niemcy nie wystawili więcej niż 25 dywizji pancernych, warto zauważyć, że ofensywa niemiecka między 22 czerwca a 6 grudnia 1941 r. - była najdziwniejszym osiągnięciem sił zbrojnych” - napisał po wojnie jeden z twórców wojsk pancernych, wybitny angielski teoretyk użycia broni pan-

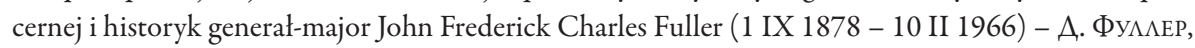
Вторал мировая война 1939-1945 г2., Москва 1956, с. 259.
} 
Przeciwko Frontowi Południowo-Zachodniemu generał-pułkownika Michaiła Kirponosa (12 stycznia 1892 - 20 września 1941) Niemcy skoncentrowali1 Grupę Pancerną generał-pułkownika Ewalda von Kleista (8 sierpnia 1881 - 13 listopada 1954), która miała być swoistym pancernym taranem do przełamania rosyjskiej obrony i późniejszych działań oskrzydlających. Michaił Kirponos miał do dyspozycji aż 10 korpusów zmechanizowanych i samodzielne jednostki pancerne (łącznie 5826 czołgów, w tym 1558 pojazdów typu T-34 i KW oraz ponad 400 samochodów pancernych z armatami) oraz 4 brygady przeciwpancerne z działami ciągniętymi za pomocą ciągników i samochodów (192 działa kalibru 76 mm, 192 działa 85 mm i 86 dział $107 \mathrm{~mm}$ ). Natomiast niemiecka 1. Grupa Pancerna posiadała jedynie trzy korpusy pancerne (liczące łącznie 728 czołgów, z czego tylko 80 były to czołgi średnie Panzerkampfwagen IV $^{12}, 195$ - to Panzerkampfwagen III ${ }^{13}$, reszta zaś to przestarzałe lekkie czołgi Panzerkampfwagen I i II $\left.{ }^{14}\right)$. Żaden z niemieckich czołgów nie mógł zniszczyć radzieckiego czołgu średniego T-34, nie mówiąc już o czołgach ciężkich KW. Niemcy skupili swe siły pancerne przeciw głównej magistrali Łuck-Kijów, przez co na wielu innych odcinkach frontu Wehrmacht w praktyce nie posiadał czołgów lub jedynie niewielką ich liczbę ${ }^{15}$. Niemcy nie mieli też zdecydowanej przewagi w powietrzu, o czym do dziś lubią pisać autorzy rosyjscy, tłumaczący przyczyny klęski Armii Czerwonej latem1941 r. ${ }^{16}$ Jak widać - analizując siły obu stron - zgodnie z wszystkimi kanonami sztuki wojennej Wehrmacht w tych okolicznościach (przynajmniej w teorii) nie powinien odnieść sukcesu. Dlatego

12 Opancerzenie: $30-50 \mathrm{~mm}$; uzbrojenie: armata $75 \mathrm{~mm}$ i dwa karabiny maszynowe 7,92 $\mathrm{mm}$.

13 Opancerzenie: $16-40 \mathrm{~mm}$; uzbrojenie: armata $50 \mathrm{~mm}$ i dwa karabiny maszynowe 7,92 $\mathrm{mm}$.

${ }_{14}$ Opancerzenie: $10-30 \mathrm{~mm}$; uzbrojenie: armata $20 \mathrm{~mm}$ i karabin maszynowy 7,92 $\mathrm{mm}$.

15 Taktyka Niemców była dobrze znana w ówczesnej literaturze. Taktyka Blitzkriegu znalazła zastosowanie w polskiej i francuskiej kampanii w 1939 i 1940 r. Wszystko to zostało znakomicie przeanalizowane i przedstawione w książce Nowe formy walki (Новые формь борьбы: Опьти исследования современных войн), wydanej w 1940 r., autorstwa G.S. ISSERSONA (Г.С. ИССЕРСОНA), wkrótce poddanego represjom. Wszystkie te kwestie zostały szczegółowo omówione na spotkaniu naczelnego dowództwa Armii Czerwonej w dniach 23-31 XII 1940 r.

16 Rankiem 22 VI 1941 r. cały 5 Korpus Luftwaffe wspierający Grupę Armii „Południe” składał się z siedmiu grup bombowców i pięciu grup myśliwskich. W składzie korpusu było 266 bombowców (163 Ju-88 i 103 He-111) i 174 samoloty myśliwskie (Me-109). Po stronie radzieckiej były 944 bombowce (nie licząc przestarzałych TB-3) i 1166 samolotów myśliwskich (w tym 253 najnowsze MiG-3 i Jak-1). Radzieckie samoloty stacjonowały na 216 lotniskach, których wróg nie mógł zniszczyć nagłym uderzeniem dostępnych sił (A. PRICE, Luftwaffe Data Book, Hamburg 1997, s. 124). 
też do dziś historykom wojskowości trudno jest wytłumaczyć przyczyny klęski armii rosyjskiej i jej sił pancernych, której jeden z tragicznych epizodów rozegrał się w Mikołajowie 1 lipca $1941 \mathrm{r}^{17}$

Rozkazy wydawane wówczas przez dowództwo Frontu Południowo-Zachodniego nakazywały pokonać wrogą grupę pancerną w rejonie Włodzimierza Wołyńskiego i odzyskać utracone tereny przygraniczne. Patrząc na układ sił Armii Czerwonej i Wehrmachtu - zadanie było możliwe do wykonania,

17 Pod koniec XX w., kiedy nie można już było mówić o nagłym ataku na nieprzygotowany i pokojowo nastawiony Związek Radziecki, w badaniach i dobrze zredagowanych pamiętnikach - m.in. we wspomnieniach dowódcy 8. Korpusu Zmechanizowanego stacjonującego w Drohobyczu i Stryju, generała-lejtnanta Dmitrija Riabyszewa (23 II 1894 - 18 XI 1985) i jego komisarza brygady Nikołaja Popela (2 I 1901-1980) - oraz w beletrystyce i filmach zaczęła dominować nowa "kanoniczna” wersja: Sztab Generalny i J. Stalin, nie mając poprawnych informacji, dyrektywą zmusili korpusy zmechanizowane do ataku na wroga, gdyż trzeba było zorganizować obronę, poczekać na skoncentrowanie wszystkich sil, a następnie spokojnie przeprowadzić kontratak. Doskonale rozumieli to: dowódca okręgu wojskowego generał-pułkownik Michaił Kirponos i jego szef sztabu generał-lejtnant Maksim Purkajew (26 VI 1894 - 11 I 1953) oraz podporządkowani im dowódcy. Ale co oni mogli zrobić, gdy wykonanie dyrektyw Stawki było kontrolowane przez komisarza Stalina - członka rady wojskowej, komisarza korpusu Nikolaja Waszugina (18 IV 1900 - 28 VI 1941), który później zrozumiał swój błąd i się zastrzelił? Wydawało się, że wszystko było całkiem logiczne, ale to tylko kolejna fantazja propagandowa. W sztabie frontu w Tarnopolu, dokąd z rozkazu Stalina przybyli szef Sztabu Generalnego Armii Gieorgij Żukow i I Sekretarz Komitetu Centralnego Komunistycznej Partii Ukrainy Nikita Chruszczow, otrzymał on w nocy z 22 na 23 czerwca dyrektywę nr 3 Sztabu Generalnego z żądaniem ofensywy na Lublin. Moskwa słusznie uważała, że z przewagą szacowaną na 3:1 (w rzeczywistości znacznie większą), mając osłonięcie flanki od strony Karpat (Węgry jeszcze nie przystąpiły do wojny) i bagien Prypeci, korpus zmechanizowany powinien był rozbić 1 . Grupę Pancerną w każdych okolicznościach. Ofensywa w kierunku Lublina sprawiłaby, że przełamanie frontu przez Niemców byłoby niebezpieczne i pozbawione sensu. Co więcej, sukces takiego uderzenia zmusiłby Niemców do przerzucenia wojsk z kierunku mińskiego. Jednak dobrze znając system stalinowski, w którym represje zagrażały i zwykłym Ukraińcom, i generałom wysokiej rangi, uśpieni wypowiedziami wodza, bez wiarygodnych informacji o wrogu, nie tylko byli chorążowie armii carskiej Kirponos i Purkajew - którzy w przeddzień wojny zajmowali wysokie stanowiska i nie mieli odpowiedniego doświadczenia, bo Stalin rozstrzelał ich bardziej doświadczonych poprzedników - ale także bliscy wodzowi Żukow i Chruszczow, byli po prostu zdezorientowani i oddali inicjatywę w ręce wroga, zmuszając jednostki pancerne i zmechanizowane do całkowitego wykorzystania zasobów paliwowych pojazdów podczas bezcelowych marszów. Komisarz Korpusu Waszugin miał co prawda odpowiednie wykształcenie i doświadczenie wojskowe, lecz niebawem popełnił samobójstwo. Przyczyną tego desperackiego kroku mógł być bałagan organizacyjny, który dostrzegał podczas swoich wizyt w wojsku, a po wybuchu wojny obarczono go winą za błędy innych wyższych dowódców i nieprzygotowanie wojsk do wojny. Natomiast główny winowajca klęski i twórca systemu, Stalin, nadal pozostaje ikoną ( $\Lambda$. КРИвИзЮК, О. Юрчук, op. cit., s. 206-220). 
tym bardziej że Georgij Żukow rozkazał dowódcy 6. Armii generał-lejtnantowi Iwanowi Muzyczence przerzucić niezwłocznie na prawą flankę armii najlepiej wyposażony 4 . Korpus Zmechanizowany generał-majora Andrieja Własowa ${ }^{18}$, mający w swym składzie 892 czołgi, w tym 414 KW i T-34. Jak się jednak okazało, I. Muzyczenko nie wykonał tego rozkazu, pozostawiając korpus do osłony Lwowa, choć miasto w tym czasie nie było zagrożone. Ponadto próbował pozyskać wsparcie 8. Korpusu Zmechanizowanego, strasząc M. Kirponosa setkami czołgów, jakie rzekomo miały zagrażać wspomnianemu miastu.

Mikołajów znajdował się w strefie 26. Armii generał-lejtnanta Fedora Kostenki (22 lutego 1896 - 26 maja 1942), którego sztab znajdował się w Dobromilu (15 km na południe od Przemyśla). Podstawową siłą uderzeniową tej armii był 8 . Korpus Zmechanizowany generał-lejtnanta Dmitria Riabyszewa (12. i 34. Dywizja Pancerna oraz 7. Dywizja Zmotoryzowana), który liczył 932 czołgi (według wspomnień byłego dowódcy) lub od 858 do 899 czołgów (według różnych opracowań), w tym ponad 100 czołgów T-34 i KW oraz 211 samochodów pancernych z armatami. Korpus 22 czerwca 1941 r. ruszył w kierunku granicy - w trakcie tego przegrupowania 7. Dywizja Zmotoryzowana wieczorem tego dnia przeszła przez Mikołajów. Rankiem 23 czerwca przez miasto przemieściła się także część oddziałów 12. Dywizji Pancernej. Niemiecki zwiad powietrzny wykrył te przegrupowania jednostek 8. Korpusu Zmotoryzowanego, które zmierzały w kierunku Przemyśla. Ofensywę wojsk radzieckich powstrzymała niemiecka 17. Armia, która zabezpieczała ten kierunek siłami 101. Dywizji Piechoty Lekkiej. Jej oddziały zmusiły siły radzieckie, które przekroczyły rzekę San, do odwrotu ${ }^{19}$. W kolejnych dniach niemiecka 101. Dywizja Piechoty Lekkiej pozostawała do 27 czerwca w rejonie Przemyśla, walcząc z radziecką 99. Dywizją Strzelecką ${ }^{20}$.

18 Tego samego Andrieja Własowa, który później w niewoli niemieckiej utworzył i stał na czele ROA (Rosyjskiej Armii Wyzwoleńczej).

19 Autorzy radzieccy pisali, że straż graniczna wypędziła Niemców za rzekę San już 23 czerwca, lecz w rzeczywistości Niemcy wycofali się na rozkaz swojego dowództwa. Dywizja piechoty lekkiej była jednostką przeznaczoną do działania na trudnym, niedostępnym dla czołgów terenie. $Z$ tego powodu składała się tylko z dwóch pułków piechoty i pułku artylerii o zmniejszonym składzie (dwie baterie po 4 działa w każdym dywizjonie). Dywizja powstała dopiero 10 XII 1940 r. i wzięła udział tylko w fazie końcowej kampanii przeciwko Jugosławii. Cały jej sprzęt był ciągnięty przez konie, a piechota przemieszczała się na rowerach oraz wozach konnych.

${ }^{20}$ W 1940 r., kiedy dowodził nią Andriej Własow, była to jedna z najlepszych dywizji piechoty Armii Czerwonej. 
W tym czasie sztab M. Kirponosa (dowódcy Frontu Południowo-Zachodniego), ulegając namowom dowódcy 6. Armii generał-lejtnanta I. Muzyczenki, przerzucił 8. Korpus Zmechanizowany na północ od Lwowa, choć nie było takiej potrzeby. Przegrupowanie nie przebiegało bez problemów, gdyż jednostki radzieckiego korpusu nie posiadały odpowiednich map, co sprawiło, że często błądziły, zużywając niepotrzebnie większość zapasów paliwa ${ }^{21}$. W rezultacie utraciły one bez bezpośredniego kontaktu $\mathrm{z}$ wrogiem niemal połowę posiadanych czołgów, którym zabrakło paliwa ${ }^{22}$. W kolejnych dniach 8 . Korpus Zmechanizowany wziął udział w walkach pod Brodami i Dubnem, po których jego resztki wycofały się 1 lipca 1941 r.w okolice Płoskirowa (od 1954 r. Chmielnicki).

W konsekwencji wspomnianego przegrupowania 8. Korpusu Zmechanizowanego 1 lipca 1941 r. w Mikołajowie nie powinno być czołgów tego korpusu, a zwłaszcza czołgów KW. W radzieckiej 26. Armii ciężkie czołgi tego typu były tylko w jednostkach 8. Korpusu Zmechanizowanego. Można jednak przypuszczać, że w rejonie miasta pozostały czołgi, które z powodu defektów lub braku paliwa nie mogły jechać dalej, a w raportach 8. Korpusu Zmechanizowanego ujmowano je jako pojazdy utracone. W tym czasie armia radziecka - w przeciwieństwie do armii niemieckiej - nie posiadała mobilnych jednostek remontowych i ewakuacyjnych, przez co załogi czołgów były zmuszone samodzielnie dokonywać napraw i zdobywać paliwo. Dodatkowym problemem był brak sprawnej łączności radiowej, bez której maszyny opóźnione w marszu traciły kontakt z własnymi jednostkami, a ich załogi nie wiedziały, gdzie się w danym momencie znajdowały i dokąd miały dalej jechać (radiostacje były tylko w maszynach dowodzenia). Czołgi dołączały więc zapewne do napotkanych po drodze jednostek działających w pasie operacyjnym 26. Armii. Który z dowódców piechoty nie chciałby przyjąć takich czołgów? Niestety dokumenty 26 . Armii zaginęly podczas okrążenia armii pod Humaniem, nie ma więc możliwości zweryfikowania tej hipotezy.

Dnia 27 czerwca 1941 r. radziecka 26. Armia zaczęła wycofywać się ku Dniestrowi w kierunku Mikołajowa, dokąd następnego dnia przybyło jej dowództwo. Odwrót był zabezpieczany przez 99. Dywizję Strzelecką. Z kolei w awangardzie niemieckiego 52. Korpusu Armijnego ruszyła wspomniana wcześniej

${ }^{21}$ Czołgi T-34 miały zasięg na drodze do $400 \mathrm{~km}$, w terenie - $350 \mathrm{~km}$; KW - odpowiednio $140 \mathrm{~km}$ i $80 \mathrm{~km}$, po czym konieczne było przeprowadzenie konserwacji silnika.

${ }^{22}$ Dowództwo korpusu meldowało, że maszyny przejechały $495 \mathrm{~km}$, a straty w pojazdach wyniosty 50 procent (Е. АРИг, Механизированные корпуса РККА в бою, Москва 2005, с. 269). 
101. Dywizja Piechoty Lekkiej, która już 27 czerwca zajęła opuszczony Przemyśl i pod koniec dnia wkroczyła do Dobromila. Na czele dywizji poruszały się batalion rozpoznawczy i 229. Pułk Piechoty, które 28 czerwca dotarły do miasteczka Rudki, a 29 czerwca ich żołnierze spędzili noc w Komarnie. W tym czasie dowództwo radzieckiej 26. Armii przekroczyło Dniestr i 30 czerwca pozostawiło do osłony przeprawy 206. Pułk Strzelecki 99. Dywizji Strzeleckiej, który jeszcze rankiem 1 lipca (według dowództwa armii) bronił się na rubieży DrohowyżRozwadów-Weryń. Mikołajów był więc już opuszczony, jako osłonę zaś pozostawiono tam jedynie czołgi, wśród których były pojazdy pancerne z 8 . Korpusu Zmechanizowanego, które dołączyły do 8. Korpusu Strzeleckiego. Pojazdom zapewne brakowało paliwa, o czym może świadczyć fakt, że czołgi typu BT zostały porzucone przy wjeździe do miasta od strony Drohowyża (ryc. 7 i 8).
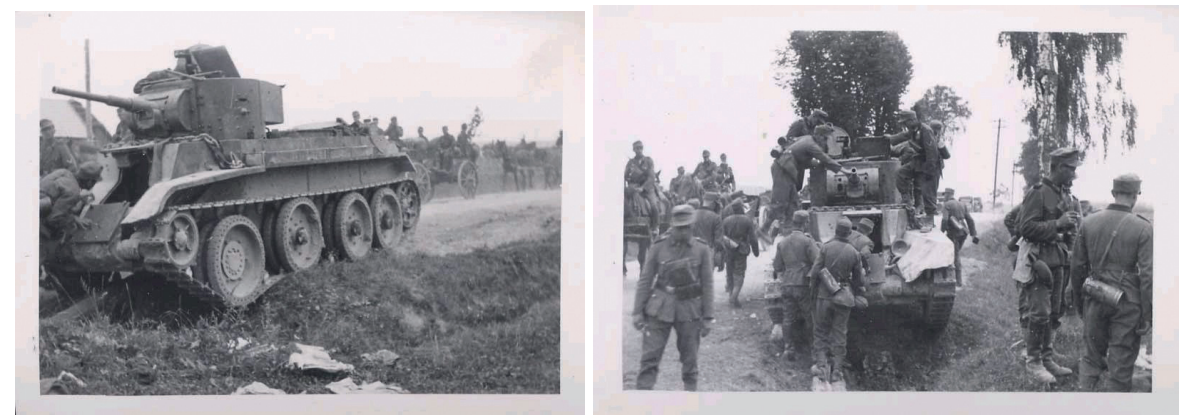

Ryc. 7 i 8. Porzucone przez załogi czołgi BT-7 przy drodze do Drohowyża (źródło: Я. Myxa, Загадки миколаївських танків http://mykolaiv.info/statti-ta-naukovi-pratsi/zagadki-mikolayivskih-tankiv.html, dostęp: 15 VII 2021)

Dwa czołgi KW i dwa BT wjechały na rynek mikołajowski wraz z samochodem sztabowym i motocyklem (nota bene 206. Pułk Strzelecki nie posiadał własnego logistycznego oddziału paliwowo-smarowego). Czołgi zajęły pozycje obronne po obu stronach placu. Prawdopodobnie rozkazano im związać wroga walką na jakiś czas, aby wspomniany pułk mógł się wycofać. Czołgom szybko skończyło się paliwo - można tak sądzić, gdyż czołgiści z KW-2 nie staranowali armaty kadłubem swego wozu, nie mieli też możliwości opuszczenia niżej lufy, tak aby trafić niemiecką $37 \mathrm{~mm}$ armatę przeciwpancerną strzelającą do nich z końca współczesnej ul. Czeszeki. Widząc, że czołgi nie manewrują, Niemcy rozmieścili swoje $37 \mathrm{~mm}$ działa przeciwpancerne w bliskiej odległości i prawdopodobnie z łatwością zniszczyli oba BT. Najprawdopodobniej unieruchomiony 
czołg KW-2 po ostrzelaniu domu Winicza-Szora, w którym zginęli żołnierze niemieccy, został wysadzony w powietrze przez własną załogę i eksplodował po zdetonowaniu amunicji znajdującej się w jego wnętrzu ${ }^{23}$.

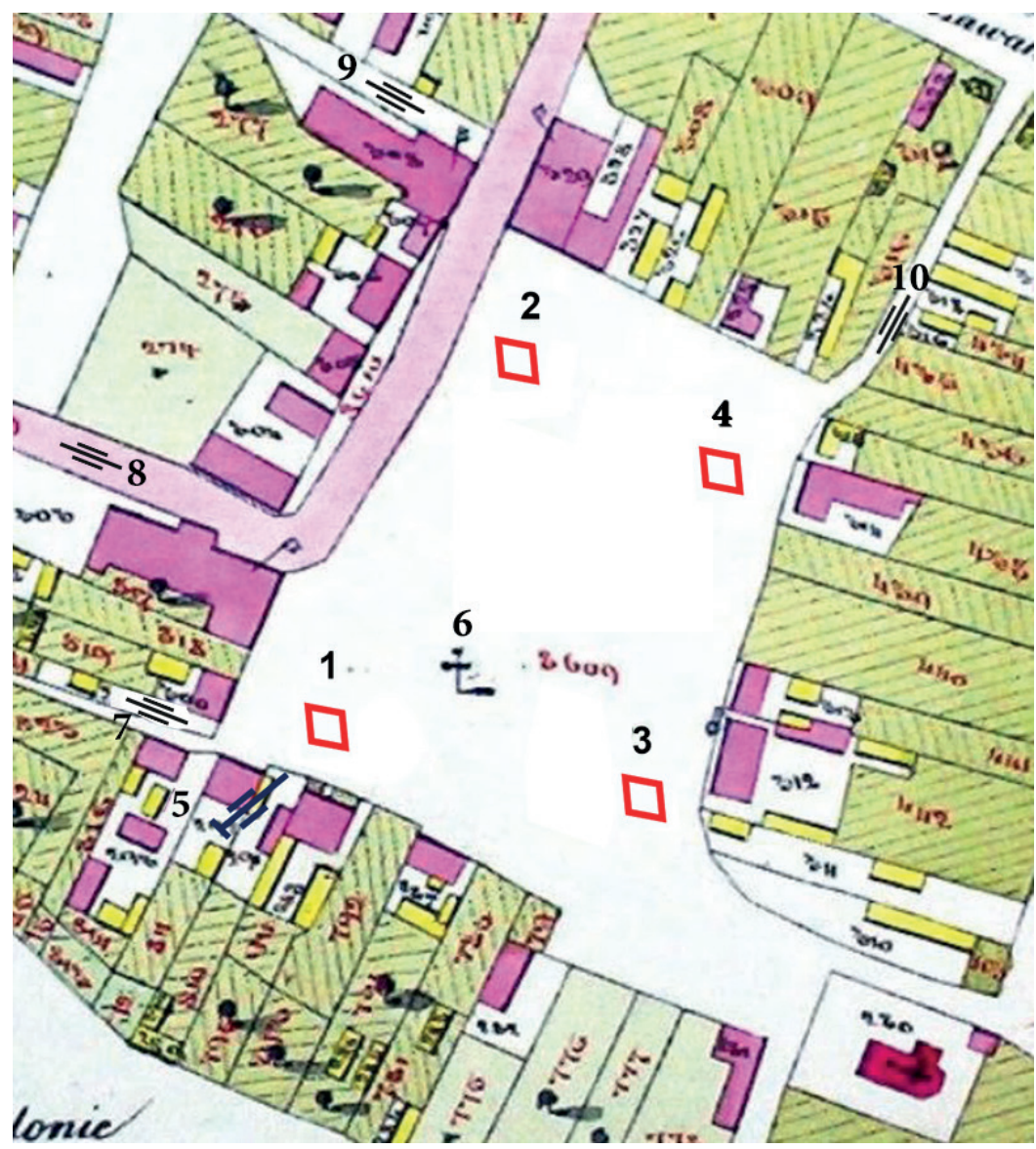

Ryc. 9. Plac Rynek w Mikołajowie nad Dniestrem (oprac. autora)

Legenda: 1 - czołg KW-2; 2 - czołg KW-1; 3 i 4 - czołgi BT zniszczone na początku boju z niemieckich armat $37 \mathrm{~mm}$ przeciwczołgowych; 5 - pozycja niemieckiej rusznicy przeciwpancernej sPzB-41 (odległość do KW-2 mniej niż 20 m); 6 - zburzony zabytkowy kamienny krzyż; 7 - stanowisko niemieckiej armaty $37 \mathrm{~mm}$ (na bocznej ulicy, obecnie ul. Sebastiana Czeszeka); 8 - stanowisko niemieckiej armaty $37 \mathrm{~mm}$ (na głównej ulicy w kierunku Stryja, obecnie ul. Metropolity Andrzeja Szeptyckiego); 9 - pozycja niemieckiej armaty $37 \mathrm{~mm}$ (na bocznej ulicy przy skrzyżowaniu z główną ulicą w kierunku Lwowa, obecnie ul. Dmytra Stasiwa); 10 - stanowisko niemieckiej armaty $37 \mathrm{~mm}$ (boczna ulica, obecnie ul. Pryszlakiw).

${ }^{23} \Lambda$. Войтович, Загаджи „миколаївських” танків, „Громада” 2009 (Миколаїв) - numery z 30 kwietnia, 8, 13, 15, 19, 26 i 29 maja, 2 i 5 czerwca oraz 20 września. 
Nieco odmienny przebieg wydarzeń z 1 lipca na mikołajowskim rynku zawiera raport dowódcy wywiadu 101. Dywizji Piechoty Lekkiej. Niemiecki oficer, zgłaszając zniszczenie czterech czołgów, nazwał czołg KW-1 „czołgiem nieznanego typu”, a KW-2 „15 cm haubicą szturmową” (KW-2 miał 152 mm haubicę czołgową M-10T), która „została przebita z karabinu przeciwpancernego 41. Załoga radzieckiego czołgu pokazywała, że poddaje się, po czym rzuciła granatami i została zniszczona w walce. Pożar maszyny spowodował eksplozję" ${ }^{24}$. W tym samym raporcie odnotowano również zdobycie 21 ciężarówek i 3 czołgów. Tę ostatnią informację należy odnieść do wspomnianych już wyżej pojazdów, porzuconych przez załogi przy wjeździe do miasta od strony Drohowyża. Nadmieniono też o braku jeńców, co oznacza, że zginęli wszyscy czołgiści, w tym załogi dwóch czołgów BT. Wspomniany w raporcie „karabin 41” to lekka armata przeciwpancerna kalibru $28 \mathrm{~mm}$ (sPzB-41 firmy Mauser).

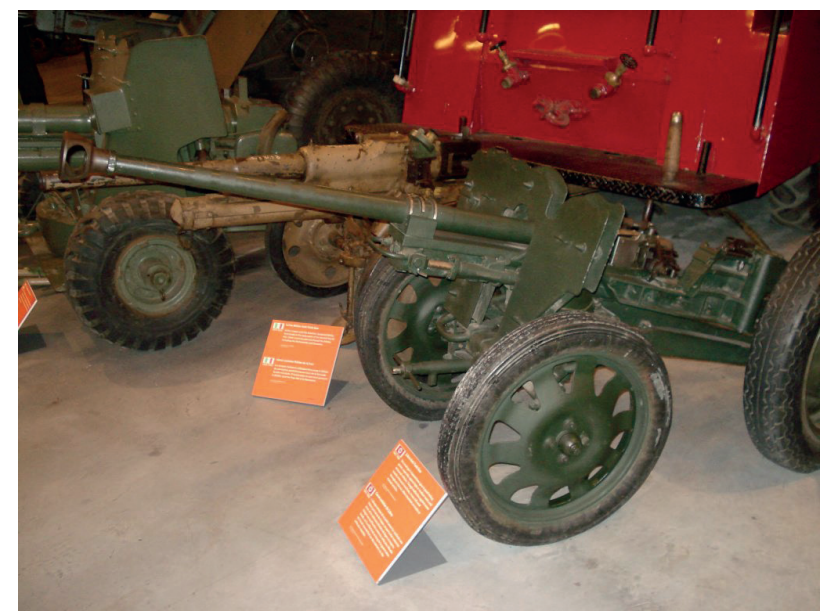

Ryc. 10. Niemiecka lekka armata przeciwpancerna kalibru $28 \mathrm{~mm}$ (źródło: https://commons.wikimedia.org/wiki/File:2.8_cm_sPzB_41_Canadian_ War_Museum_Ottawa_1.jpg, dostęp 15 VII 2021)

Sprzęt ten o masie 229 kilogramów (obsługiwało go trzech żołnierzy) został przyjęty na wyposażenie armii niemieckiej w lipcu 1940 r., jednak w czerwcu 1941 r. Wehrmacht posiadal jedynie 183 egzemplarze tej broni. Ta armata strzelająca pociskami kumulacyjnymi mogła przebić z odległości 100 metrów

24 Я. МухА, Загадки миколаївських танків. Повертаючись до надрукованого, „ГромаАа” 2010, numer z 23 listopada. 
pancerz o grubości do $52 \mathrm{~mm}$. Położenie KW-2 na rynku w Mikołajowie sugeruje, że żołnierze niemieccy mogli zbliżyć się do radzieckiego czołgu na odległość zaledwie 20 metrów. W takich warunkach zwiadowcy ze 101. Dywizji Piechoty Lekkiej mogli w praktyce zniszczyć KW-2 (jego załogę stanowiło sześć osób, w tym jeden oficer), ale tylko z odległości nie większej niż 20 metrów ${ }^{25}$. Ten przypadek jest wyjątkowy, bowiem w walce takie rzeczy zdarzały się bardzo rzadko. Czołg, którego pancerz z normalnej odległości nie zawsze mógł zostać przebity nawet przez $88 \mathrm{~mm}$ działo przeciwlotnicze, został zniszczony przez lekką armatę przeciwpancerną!

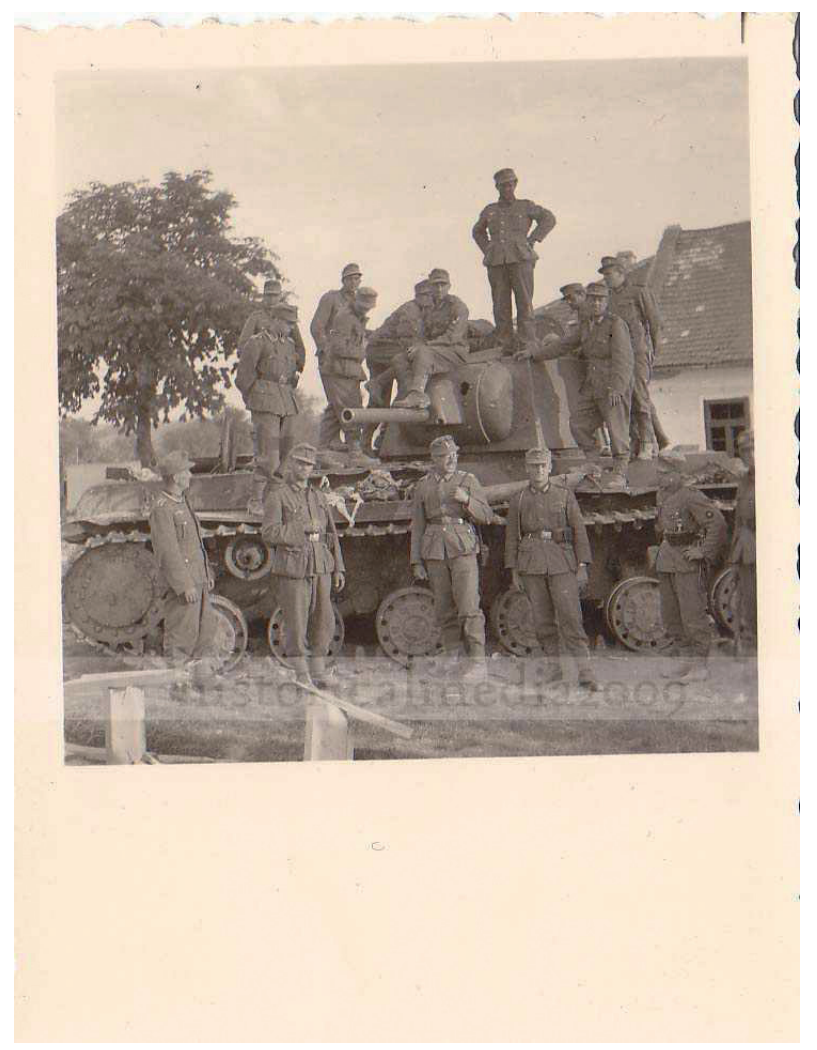

Ryc. 11. Żołnierze z niemieckiej 101. Dywizji Piechoty Lekkiej przy wraku czołgu KW-1 (źródło: А. Исаев, Бои на Украине 1941, „Фронтовая иллюстрация” 2004, № 4, с. 43)

25 Главное артиллерийское управление Красной Армии. 28/20 мм немеикая противотанковая пушка образца 1941 г., Москва 1944, с. 34; М. КолОмИЕЦ, Противотанковая артиллерия вермaxma, Москва 2006, с. 68; A. LÜDEKE, Deutsche Artillerie Geschütze, Stuttgart 2010, s. 44-48. 
Bój na mikołajowskim rynku trwał trzy godziny - w tym czasie zbliżyły się do miasteczka inne frontowe jednostki niemieckie, dzięki czemu w krótkim czasie rynek został otoczony, radzieccy czołgiści zaś nie mogli się wycofać. Nie jest jasne, co stało się z czołgiem KW-1. Na zdjęciach wygląda on na niemal nienaruszony - ma tylko otwór z boku lufy, który mógłby zrobić pocisk z tej samej lekkiej armaty przeciwpancernej kalibru $28 \mathrm{~mm}$, i to z bliskiej odległości (oczywiście przez przypadek, bo nikt specjalnie nie celował w działo $76 \mathrm{~mm}$ ). Czołg nie miał też paliwa - tym samym nie mógł się poruszać, ale jego trzy karabiny maszynowe DT 7,62 mm były poważną bronią przeciwko piechocie niemieckiej. Dlaczego w czołgu zostało tylko dwóch z sześciu członków załogi? Może pozostałym udało się uciec i gdzieś schować? Ironia losu polegała na tym, że czołg zatrzymał się przy tabliczce „Uwaga! Chodzenie po trawie, niszczenie drzew i kwiatów jest surowo zabronione". Po bitwie żołnierze niemieckiego 229. Pułku Piechoty chętnie fotografowali czołgi, a zwłaszcza KW-1 (ryc. 11). Większość z nich nigdy nie widziała takich czołgów. Razem z nimi fotografowali się także mieszkańcy Mikołajowa.

Los żołnierzy 206. Pułku Strzeleckiego 99. Dywizji Strzeleckiej, któremu walki stoczone w centrum Mikołajowa pozwoliły oderwać się od wroga, był równie tragiczny jak los radzieckich czołgistów. Dywizja ta (wchodząca w tym czasie w skład 8. Korpusu Strzeleckiego) dotarła do Humania, gdzie ocaleli do tej pory jej żołnierze - wraz z dowódcą generał-majorem Michaiłem Sniegowem (12 listopada 1896 - 25 kwietnia 1960) - zostali wzięci do niewoli. Po latach spędzonych w niemieckich obozach jenieckich trafili później do obozów sowieckich, oskarżeni o zdradę. Generał M. Sniegow był jednym z nielicznych radzieckich generałów, którzy powrócili z niewoli (większość rozstrzelano w latach 1947-1950) i po przejściu przez obozy filtracyjne służył w wojsku w latach 1947-1959. Niestety mimo głośnych stwierdzeń, że „nikt nie jest zapomniany" - imiona poległych w Mikołajowie czołgistów nie zostały jeszcze ustalone ${ }^{26}$.

${ }^{26}$ Dzisiaj, gdy siły antyukraińskie ponownie zaczęły fabrykować dowody na „krwawe zbrodnie ukraińskich burżuazyjnych nacjonalistów”, w Internecie pojawiła się wersja o rzekomo „wyklętych” nacjonalistach, którzy nagle zabili „biednych” czołgistów, naprawiających maszyny w centrum miasta, a następnie ten czołg podpalili. Wersja ta należy do tej samej serii wniosków współczesnych „badaczy”, którzy usprawiedliwiając Stalina, próbują udowodnić, że 85 procent czołgów Armii Czerwonej było niesprawnych i z wykorzystanym zasobem silnikowym. Nie powinno się nawet dyskutować nad takimi wersjami (М. Солонин, 22 июня. Анатомия катастрофьь, Москва 2008, с. 329-330). 


\section{BIBLIOGRAFIA}

\section{Źródła drukowane}

Куприянов А., Главное артиллерийское управление Красной Армии.28/20 мм немечкая противотанковая пушка образиа 1941 г., Москва 1944 (Kuprianov A., Glavnoye artilleriyskoye upravleniye Krasnoy Armii. 28/20 mm nemetskaya protivotankovaya pushka obraztsa 1941 g., Moskva 1944).

\section{Prasa}

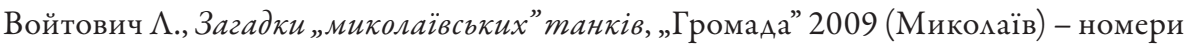
від 30 квітня, 8, 13, 15, 19, 26 і 29 травня, 2 і 5 червня та 20 вересня (Voytovych L., Zahadky „mykolayivs'kykh” tankiv, „Hromada” 2009 (Mykolayiv) - nomery vid 30 kvitnya, 8, 13, 15, 19, 26 i 29 travnya, 2 i 5 chervnya ta 20 veresnya).

Муха Я., Загадки миколаївських танків. Повертаючись до надрукованого, „ГромаАа” 2010 (Миколаїв) - випуск віА 23 мистопада (Mukha Y., Zahadky mykolayivs'kykh tankiv. Povertayuchys' do nadrukovanoho, „Hromada” 2010 (Mykolayiv) - vypusk vid 23 lystopada 2010).

\section{Opracowania}

Гнатів Я., Коли прокидається лищар, Аьвів 2006 (Hnativ Y., Koly prokydayet'sya lytsar, L'viv 2006).

Ариг Е., Механизированные корпуса РККА в бою, Москва 2005 (Drig Ye., Mekhanizirovannyye korpusa RKKA v boyu, Moskva 2005).

Исаев А., Боина Украине 1941, „Фронтовая им юстрация” 2004, №4 (Ysaev A., Boy na Ukrayne 1941, „Frontovaya yllyustratsyya” 2004, № 4).

Иссерсон Г., Новые формь борьбъ: Опьт исследования современных войн, Военгиз 1940 (Issersong S., Novyye formy bor' by: Opyt issledovaniya sovremennykh voyn, Voyengiz 1940).

Коломиец М., Противотанковая артиллерия вермахта, Москва 2006 (Kolomiyets M., Protivotankovaya artilleriya vermakhta, Moskva 2006).

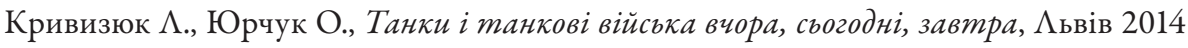
(Kryvyzyuk L., Yurchuk O., Tanky i tankowi viys'ka vchora, sohodni, zavtra, L'viv 2014).

Маркевич А., Орел М., Стасив В., Николаев, [в:] История городов и сел Украинской СРСР. Аввовскал область, Киев 1978 (Markevich A., Orel M., Stasiv V., Nikolayev, [w:] Istoriya gorodov isel Ukrainskoy SRSR. L'vovskaya oblast, Kiyev 1978).

Солонин М., 22 июня. Анатомия катастрофьь, Москва 2008 (Solonin M., 22 iуипуа. Anatomiya katastrofy, Moskva 2008). 
Федусевич В., Хроніка парохії і міста Миколаїва над Аністром, [в:] Миколаївщина. Збірник наукових статей, т. 1: Відпов, реА. А. Войтович, Аьвів 1998 (Fedusevych V., Khronika parokhiyi i Mista Mykolayiva nad Dnistrom, [w:] Mykolayivshchyna. Zbirnyk naukovykh statey, t. 1: Vidpov, red. L. Voytovych, L’viv 1998).

Фумлер А., Вторая мировая война 1939-1945 г2., Москва 1956 (Fuller D., Vtoraya mirovaya voyna $1939-1945 \mathrm{gg}$., Moskva 1956).

Lüdeke A., Deutsche Artillerie Geschütze, Stuttgart 2010.

Price A., Luftwaffe Data Book, Hamburg 1997.

\section{Netografia}

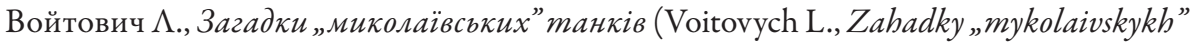
tankiv), http://mykolayiv.org/detail/zagadki-mikolayivskih-tankiv/photo/ (dostęp: 15 VII 2021).

Муха Я., Загадки миколаӥвських танків (Mukha Y., Zahadky mykolaivskykh tankiv), http://mykolaiv.info/statti-ta-naukovi-pratsi/zagadki-mikolayivskih-tankiv.html (dostęp: 15 VII 2021).

https://commons.wikimedia.org/wiki/File:2.8_cm_sPzB_41_Canadian_War_Museum_ Ottawa_1.jpg (dostęp: 15 VII 2021).

\section{Leontiy Voitovych (Леонтій Войтович)}

\section{TANKS FIGHT ON THE TOWN SQUARE IN MYKOLAIV ON THE DNIESTER RIVER ON THE FIRST DAY OF JULY 1941}

Summary. The article shows some of the causes of the defeat of the Soviet army at the beginning of the Soviet-German war, based on one of the tanks clashes on the city square in Nikolaev on the Dniester. The circumstances of this clash are partly known, thanks to the preserved German photos. The text attempts to explain how the German 101st Light Infantry Division, which did not include any tanks, could defeat the Soviet units equipped with the then most powerful KW-1 and KW-2 tanks. The reasons for the mistakes of the Soviet command were also analyzed, as they were unable to determine the directions of the enemy's main strikes and could not organize an effective defense, having an advantage, both in man and military equipment. In this context, one can clearly see the heroism of ordinary Soviet soldiers who fought to the end. Particular attention was paid in the text to the specificity of tanks combat in urbanized area, in which the Germans managed to destroy the KW-1 heavy tanks, which were difficult to destroy even with the famous $88 \mathrm{~mm}$ anti-aircraft gun - in this case, the German soldiers managed to destroy them with a light anti-tank gun caliber $28 \mathrm{~mm}$.

Keywords: tanks fight, beginning of the Soviet-German war, Mykolaiv, urban combat 